\title{
Liennytys ja tieteellinen yhteistyö
}

Hampurissa järjestettiin 18. 2.-3. 3. tänä vuonna Euroopan turvallisuus- ja yhteistyökokouksen osanottajamaiden edustajien tieteelline.ı foorumi. Foorumin lähtökohdat sisältyvät jo ETY-asiakirjaan. Tieteellä on mitä luonnollisimmalla tavalla tärkeä asema kansainvälisen yhteistyön kehittämisessä: välittömästi, koska monien ongelmien ratkaiseminen edellyttää tutkimusyhteistyön lisäämistä, sekä välillisesti, edellyttäähän tieteen kehitys nykyään sinällään kansainvälisyyttä, yhteyksien tiivistämistä, keskustelun ja kokemusten vaihdon kehittämistä.

Nämä molemmat puolet sisältyivät Hampurin kokouksen työlistaan. Lopputiedonannossa käsitellään pääasiassa tieteellisen kanssakäymisen kehitystä ETY-kokouksen jälkeen. Joillakin aloilla on selvästi kyetty lisäämään yhteistyötä, mutta toisilla on edetty heikommin - tässä tiedonannon arvio. Kansainvälinen tieteellinen yhteistyö vaatii edelleen parantamista kaikissa eri muodoissaan, sekä valtioiden välisin sopimuksin että eri alojen yhteistyöprojekteja kehittäen. Tiedonannossa korostetaan myös tutkijakoulutuksen merkitystä ja suositellaan kansainvälisten seminaarien ja kurssien järjestämistä erityisesti nuorille tutkijoille.

Yleisen jakson ohella kokouksen tiedonantoon on sisällytetty neljän jaoston raportit aiheinaan luonnontieteet (vaihtoehtoisten energialähteiden kehittäminen sekä ravinnontuotanto), lääketiede (sydän-, verisuoni-, kasvainja virustaudit) sekä yhteiskuntatieteet (elinympäristö ja kaupungistuminen). Raporteissa kartoitetaan kansainvälisten yhteistutkimusten mahdollisia teemoja, joista ei ole puutetta.

Tiedonannossa todetaan, että edistyminen tieteellisen yhteistyön kehittämisessä on riippuvaista koko ETY-asiakirjan noudattamisesta kaikissa maissa. Tämä varmasti pitää paikkansa; tieteellinen yhteistyö ei voi olla yleisen kansainvälisen ilmapiirin ulkopuolella.

Liennytyksen vaikeudet ovat tällä hetkellä ilmeisinä kaikkien nähtävillä. Yhtä ilmeistä on, että vaikeuksien taustana on hyvinkin järjestelmällinen yritys murentaa liennytyksen ilmapiiriä kansainvälisen elämän eri alueilla; erään moskovalaisen nallen kantamaan olympiasoihtuun kohdistuva kylmä viima on tämän eräs osa. Tiede ei ole myöskään tämän asetelman ulkopuolella: Nature-lehden mukaan Carterin hallinto on alkuvuonna evännyt viisumit neuvostoliittolaisilta osanottajilta kahteen USA:ssa järjestettyyn tieteelliseen kokoukseen, perusteluna tieteellis-teknisen yhteistyön jäädyttämisesta aiemmin tehty päätös - konferenssien aiheena oli tietokonetekniikka sekä lasertekniikka. Myös joitakin tieteellisiä järjestöjä on USA:ssa valitettavasti saatu esiintymään idän ja lännen tieteellisen yhteistyön kehittämistä vastaan.

Liennytyksen vaikeudet ja Hampurin kokouksen teema nostavat esiin uuden näkökulman tutkijoiden vastuukysymyksiin. Uuden kylmän sodan torjuminen on nyt tehtävä, joka nivoutuu läheisesti yhteen "perinteisten", jo vuosikymmeniä esillä olleiden kysymysten kanssa. 
Tämä ei suinkaan merkitse sitä, että tutkijoista tulisi attashea-salkkuisia kongressikomeettoja, joiden henkinen työskentely liitää päätöslauselmasta toiseen. Pääasiana on tieteellisen yhteistyön puolustaminen ja kehittäminen eri tieteenalojen eri tutkimusaiheiden yhteydessä.

Liennytyksen syventäminen on niin ilmiselvästi tällä hetkellä ainoa vaihtoehto, että sen vastustajat joutuvat ennemmin tai myöhemmin umpikujaan. Kansainvälisen tieteellisen yhteistyön laajeneminen voi tuoda umpikujan hiukan lähemmäksi.

Yrjö Haila

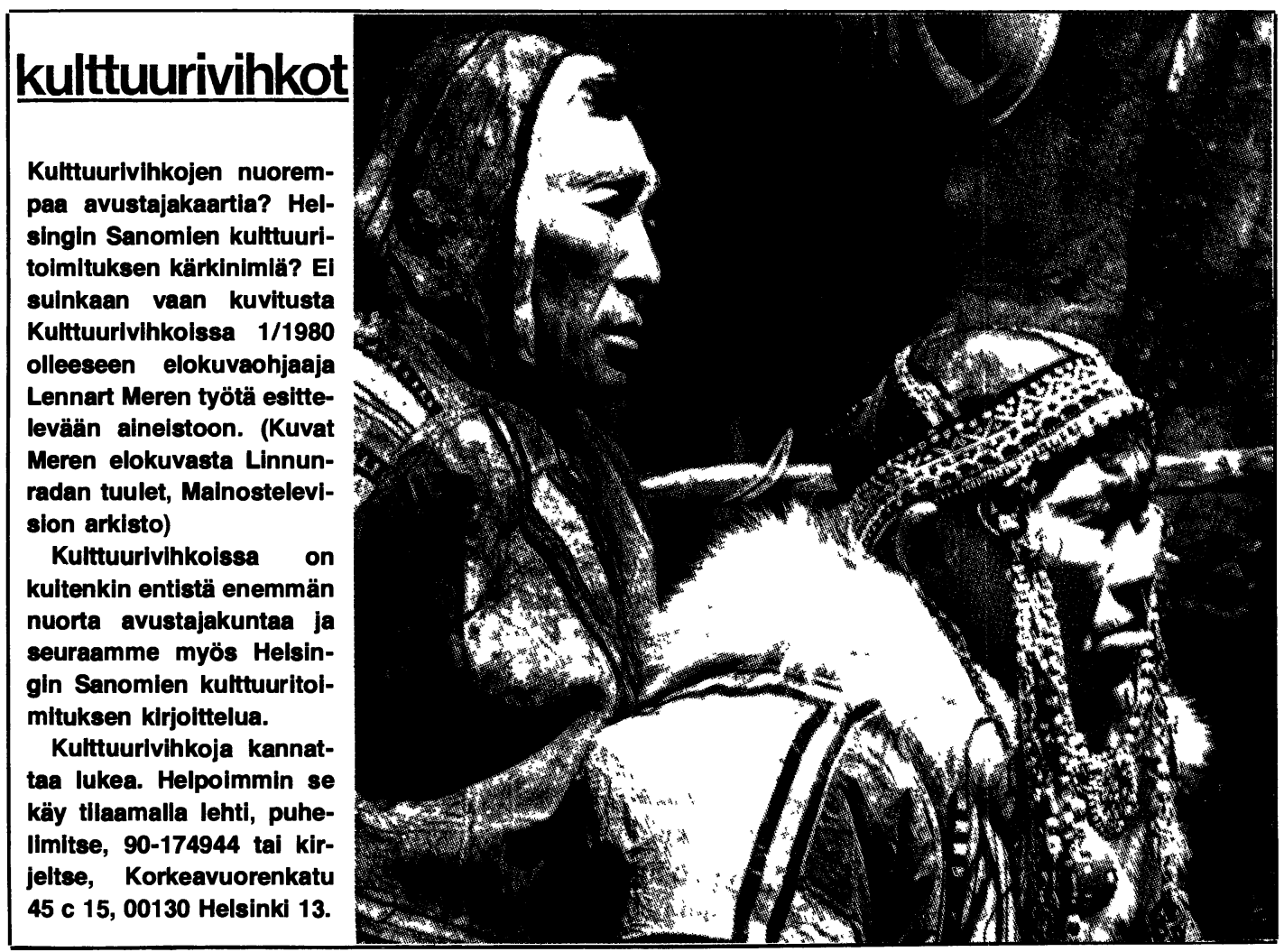

